\title{
Nicholas Cross
}

\section{Freedom Of Expression And Freedom Of Movement In The Immigration Space: Substance Over Forum}

\author{
Faculty of Law \\ Victoria University of Wellington
}

2014

Word Count: 14,997 (Does not include title page, table of contents, bibliography or non-substantive footnotes) 
Table of contents

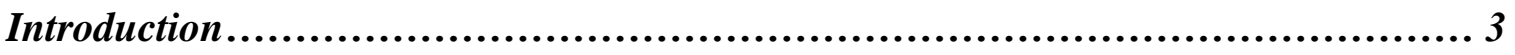

Freedom Of Expression And Freedom Of Movement: Preferred Framework.............. 5

When Can Government Restrict Freedom Of Movement? .................... 5

How Does Restricting Freedom Of Movement Restrict Freedom Of Expression?

When Is It Legitimate To Restrict Freedom Of Movement In Order To Restrict Freedom Of Expression? ................................................................. 10

Freedom Of Expression And Freedom Of Movement In The United Kingdom .........17

Human Rights And Immigration Framework .............................17

Farrakhan V Secretary Of State For The Home Department..................22

Naik V Secretary Of State For The Home Department........................29

Geert Wilders Case........................................................36

Freedom Of Expression And Freedom Of Movement In Australia: David Irving's

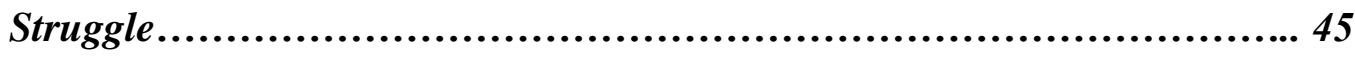

Human Rights Framework In Australia ................................45

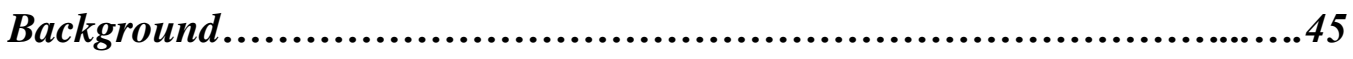

Decision And Judicial Review.............................................46

Analysis......................................................................50

Second Decision And Review .............................................56

Analysis.....................................................................59

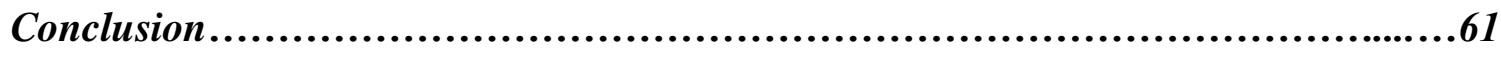




\section{Introduction}

Globalisation and the availability of information through television and the internet have been a boon for the spread of ideas and for freedom of expression. These trends have also created challenges for the regulation of expression. Those with hateful views or harmful information have just as much access to modern communication tools as the rest of us. How policy makers respond to the free flow of information raises a multitude of questions. However there is no doubt that the state still holds the upper hand in controlling the freedom of movement between borders. Despite the availability of information technology there is still a need for interpersonal communication to facilitate the freedom of expression. The freedom of movement is therefore important to enabling the freedom of expression, and states can restrict the later by restricting the former.

The aim of this paper is to comprehensively scrutinise the different approaches taken to regulating freedom of movement for the purpose of regulating freedom of expression. It looks with judicial reviews within common law jurisdictions and how the issue is managed within their existing human rights legal frameworks.

Firstly the paper will lay out a preferred approach to dealing with the regulation of freedom of expression in an immigration context, bearing in mind the rights which states have to control their borders and the justifications for doing so. The approach places strong emphasis on protecting the freedom of expression for all groups without seeking to challenge the existence or legitimacy of the ways states choose to regulate expression within their borders. It suggests that regulation should be limited to situations where it is likely that the visitor would choose to break the laws of the state they seek to visit, or where 
their visit could spark disruption involving violence which could not reasonably be controlled by law enforcement.

Secondly the paper will examine four cases from two common law jurisdictions in detail. There is an emphasis on understanding two themes. The first is explaining the broader context of human rights protection within those jurisdictions and how their approach to immigration control reflects or contradicts that protection. The second is upon critiquing and understanding the administrative law implications of the standards of review applied. Reference is made back to the preferred framework to help understand to what extent the cases stand for genuine protection of freedom of expression. 


\section{Freedom Of Expression And Freedom Of Movement: Preferred Framework}

In this section of the paper I lay out a framework for when I consider it to be justified within a free and democratic society to restrict the ability of a foreigner to enter for the purpose of restricting their ability to engage in expression. The discussion is broken up into three parts. Firstly I will look at the right and ability of states to control their own borders within an international law framework, and modern approaches to doing this by liberal democracies. Secondly I will look at justifications for the protection of freedom of expression and how they apply within the context of freedom of movement. Finally I look at when restrictions on freedom of movement on the basis of aiming to restrict freedom of expression may be justified within a free society.

\section{A When Can Government Restrict Freedom Of Movement?}

Whether it is a principle of international law that state sovereignty to exclude immigrants is absolute is a matter of dispute. ${ }^{1}$ The role of the state in controlling immigration has evolved over time. Provisions concerning the rights of aliens to travel to England for the purpose of commerce can be found as far back as the Magna Carta, with clause 41 guaranteeing the rights of merchants. ${ }^{2}$ Classical European writers in the field of international law like Vitoria, Pufendorf and Vattel appeared not to believe that the right to exclude was absolute where aliens came to the state for reasons that were legitimate or

\footnotetext{
${ }^{1}$ R Plender International Migration Law (2nd ed, Martinus Nijworth Publishers, Dordrecht, 1988) at 61.

${ }^{2}$ At 62.
} 
necessary. In particular, the right of freedom of movement was used to justify the creation of colonies in the Americas. ${ }^{3}$

However between the late $18^{\text {th }}$ century and mid-19 $9^{\text {th }}$ century, coinciding with the development of the modern nation state, European nations began passing a spate of laws controlling and restricting the movement of immigrants. ${ }^{4}$ In practice very few states argue for or act as if a right to international free movement exists. Numerous domestic courts, such as the US Supreme Court ${ }^{5}$ and the Privy Council, ${ }^{6}$ have held that the right of sovereign nations to exclude foreigners is absolute.

This does not mean that there are no generally accepted obligations for states to consider when implementing immigration policy. Firstly, states often enter into bilateral or multilateral treaties to allow free or relatively free immigration between their borders. The Schengen Agreement between European states is one example. ${ }^{7}$ Secondly, states may have obligations to particular classes of persons such as refugees although there is no universally accepted definition of a refugee and it is unlikely that there is a general obligation to accept refugees. ${ }^{8}$ Thirdly, although states may choose which countries their immigrants come from, there is widespread condemnation of policies which systematically discriminate in certain ways, for example policies with the overall aim of altering or maintaining the racial

\footnotetext{
${ }^{3}$ At 63.

${ }^{4}$ At 64 .

${ }^{5}$ Nishimura Ekiu v U.S. 142 US 651 (1892).

${ }^{6}$ Attorney-General for Canada v Cain, Gilhula [1906] A.C. 542 (PC).

${ }^{7}$ Agreement between the Governments of the States of the Benelux Economic Union, the Federal Republic of Germany and the French Republic on the gradual abolition of checks at their common borders 30 ILM 68 (signed 14 June 1985).

${ }^{8}$ Plender, above at 1 , at 394
} 
demographics of a country such as those pursued under the so called 'white Australia policy'.

States expression clear interests through immigration policy. Aside from refugee quotas, states often pursue immigration policies with the aim of regulating labour markets, ensuring that new immigrants are allowed to meet skill shortages whilst restricting immigration flow where an oversupply of labourers may cause unemployment. The significance of this is that it reflects the broader state interests in regulating labour markets to achieve economic and social policy goals. Family unification is also important in the immigration policies of many countries.

\section{B How Does Restricting Freedom Of Movement Restrict Freedom Of Expression?}

There are three major justifications for the protection of freedom of expression within a democratic society. I will look at each in turn and how the freedom of movement is related to these justifications.

The first is that freedom of expression is essential to the workings of a democratic process. In order for democracy to effectively function it essential that people feel free to express their opinions without the overbearing state threatening any kind of persecution. Individuals need to feel informed in order to engage in the democratic process. In practise this justification for freedom of expression is often the most recognised within the law, political expression is regularly afforded protection that other kinds of expression are not. It's clear that the opinions of those outside our borders are relevant to the democratic process, and that in some circumstances their ability to voice those opinions is enhanced by the freedom of movement. Expanding the number of voices available to the citizenry adds to democratic debate, particularly when those voices come from people with a level 
of expertise or prominence that would not otherwise be available within a countries citizenry.

On 15 September 2014 American journalist Glenn Greenwald made a large impact on the New Zealand general election by appearing at an event organised by a political party designed to highlight the threat of mass surveillance. ${ }^{9}$ His visit was a catalyst for the large amount of media coverage the issue received over the period he was in the country, during which his integrity and evidence for his claims was directly engaged with by the Prime Minister and Greenwald gave several interviews to various media outlets. Whilst the fact that other foreign activists like Julian Assange and Edward Snowden were able to attend the event via video link suggests that with modern technology a physical presence is not strictly necessary to engage in democratic discourse, there is no doubt that Greenwald's visit was instrumental to the success of the event.

One case directly relevant to this issue is the decision by the UK Home Secretary to deny Dutch politician Geert Wilders entry to the United Kingdom in 2009. ${ }^{10}$ Wilders was intending to enter the United Kingdom to attend a screening of his controversial anti-Islam film Fitna in the Palace of Westminster. The showing was to be hosted by two members of the House of Lords. Whilst the film itself was not banned in the United Kingdom, prohibiting a figure like Wilders from attend arguably denied the screening prominence as well as creating a chilling effect by sending a message that the views expressed in the film were illegitimate views to hold in the political arena.

\footnotetext{
9 David Fisher "Glenn Greenwald: New Zealand has spied on friends for US” (17 September 2014) NZ Herald <www.nzherald.co.nz>.

${ }^{10}$ Haroon Siddique "Dutch politician attempts to defy UK entry ban to show film critical of Qur'an" (12 February 2009) The Guardian <www.theguardian.com>.
} 
The second justification is that freedom of expression allows the working of a 'free market of ideas' to most efficiently determine the truth or falsity of ideas. Under this conception of expression, ideas are competing narratives whose popularity or 'market share' acts as a barometer for their value to society. The free operation of this market is more likely to lead to the success of better ideas than government intervention. This is firstly because government intervention presupposes that governments are able to pick out 'failed ideas', an assumption that is rejected. Secondly because the market can operate as an effective mechanism for killing bad ideas through their debunking and general unpopularity.

Under this conception, the prohibition of foreigners from engaging in freedom of movement on account of their ideas is a form of protectionism, prioritising the ideas of domestic producers over foreign competition. Whilst the domestic market may be diverse and many ideas disseminated by foreigners may compete on a level playing field through mediums which do not require the freedom of movement it still creates a double standard between the domestic and the foreign where expression of ideas by aliens is seen as more harmful or less legitimate. In some circumstances the domestic market may not specialise in producing a particular message meaning foreigners are needed in order to have that message properly disseminated. For example a speaker who represented a particular religious group which is a minority in one country may have a particular interest in listening to a prominent individual from a country whether that religion is a majority.

It's clear however that this justification is less respected, in that the governments often believe they have a role to play in regulating speech where its harms clearly outweigh its benefits. Courts in many countries provide defamation law where damages can be awarded against an individual who makes an incorrect and harmful statement. Courts will often 
issue orders banning the publication of certain material where it breaches a right to privacy or is harmful to fairness within the justice system. Many jurisdictions criminalise hate speech or expression which aims to incite violence. All of these prohibitions on speech to an extent assume a failure in the market for ideas which justifies government intervention. The later of these is most relevant to the discussion in that most often the wider harm created by hateful speech is community division and an aggressive or even violent backlash to such speech. Authorities choose to restrict the movement of certain individuals because their physical presence in a country may make them a focal point for these divisions and cause reactions.

The third justification for protecting freedom of expression is to enable self-fulfilment. Engaging in expression and debate is said to promote intellectual development and the ability to explore competing ideas has inherent benefits to the individual. Being able to express ideas freely may be important to you if a certain religious or political philosophy is central to your identity and where that idea gives your life purpose and meaning. Being able hear the ideas of others can be beneficial in a similar way.

Often the types of speakers who attract the attention of immigration regulators do so precisely because they are the most effective and popular communicators of their message. The ability to meet famous speakers may be important because the popularity or meaningfulness of an idea can be tied to its most famous communicators. This is particularly true in the case of religious leaders. Direct interpersonal communication can also be more enriching than communication through a technological medium.

\section{When Is It Legitimate To Restrict Freedom Of Movement In Order To Restrict Freedom Of Expression?}


Although it is established that states have a right to regulate entry through their borders, that does not mean they should regulate for any purpose. Immigration policy is not an end in itself, it is a means to achieve a diverse range of other ends. It is therefore important not to cloud the discussion of immigration policy with the issue of national sovereignty. Protectionist rhetoric is too often used as argumentative cover to justify policy made on the basis of prejudices rather than clearly defined policy goals matched with appropriate policy instruments.

When the state regulates who may or may not enter the country for the purpose of finding work, immigration policy is being used for the purpose of economic policy through control of the labour market. It is broadly accepted within liberal democracies that the state has a large role in regulation of this sphere of society in order to achieve desired economic and social outcomes. By contrast it is largely accepted that the state has a very limited role in regulating speech in the public sphere, in particular where this speech is of a political nature. Insofar as immigration policy is being used as a tool for regulating speech at the whim of decision makers within the executive branch of government where that speech would not otherwise be regulated, this should be condemned as illegitimate within a free and democratic society. This is especially true since there is no precedent within free and democratic societies for regulating the expression of aliens differently from speech by citizens. For example the idea of banning books written or published by foreigners or regulating web content produced outside of our own borders because we believe that local ideas are superior is scarcely imaginable except in authoritarian states.

That a person is likely to choose to commit crimes if they enter a country is a common justification for denying entry to potential immigrants. Almost by definition, the fact that 
an alien attempting to enter the country would break the law shows that there is a state interest in denying them entry. Therefore where there is a particular concern that an alien may violate hate speech laws or laws protecting the public order this may legitimately be used by the decision maker to justify their exclusion.

However two considerations need to be kept in mind when using this ground to justify exclusion to prohibit the expression of harmful ideas. Firstly the decision maker ought to consider not just whether the law is likely to be breached based on their own interpretation of the law, but how the courts will interpret the law and how law is enforced in practise. Many countries have hate speech laws or laws protecting the public order which could be interpreted as being very strict on a wide reading of the legislation but are not enforced in that way. Often courts will adopt a narrow reading of these laws in order to protect freedom of expression, especially when the meaning of these laws is ambiguous. To pick just one example, the New Zealand Supreme Court recently chose to quash a conviction for offensive or disorderly behaviour where a protester burned a New Zealand flag near an ANZAC Day commemoration service. ${ }^{11}$ The Court considered s 14 of the Bill of Rights Act $1990^{12}$ and held that it was not sufficient for the offence that others present were offended by the behaviour. Police may choose not to enforce these laws except in cases where they believe there is a strong public interest in doing so either in order to protect freedom of expression, or because they believe it will be too difficult to gain convictions under the narrow readings adopted by the courts.

\footnotetext{
${ }^{11}$ Morse v Police [2012] 2 NZLR 1.

12 Bill of Rights Act 1990.
} 
To take this point to its logical extremity, if a decision maker could justify refusing to admit an alien on the grounds they may break any law, the Minister could consider whether the alien is likely to breach totally defunct and unenforced laws. One such example is the offence of blasphemous libel under the Crimes Act $1961 .^{13}$ The enforcement of this law could have wide ranging consequences. However while the law has not yet been repealed the most recent prosecution for blasphemous libel was in 1922, and the Attorney-General would be required to give leave for any prosecutions to occur. The police have chosen to not prosecute numerous complaints, including against Canwest Media and Te Papa Museum. ${ }^{14}$ Notwithstanding this, if likelihood of committing a criminal offense of this kind were sufficient legal grounds for the Minister to refuse to allow entry, we may end up granting this type of discretion to decision makers who could use it to act as censors.

Secondly the decision maker ought to review the strength of the evidence that the alien is likely to break the law when they are in the country. In many cases an individual will have previously said things that constitute hate crimes, or even have been charged with hate crimes in another country, and this should raise concerns about the likelihood that they will commit further crimes whilst in the country. However there should be ways for the alien to prove that they have no intention of engaging in this type of speech when in the country. The decision maker ought to take into account the specific plans that the alien has for when they are in the country. If the plans are not likely to involve any real threat of hate speech or violence this should be a strong consideration in favour of allowing entry. They should

\footnotetext{
${ }^{13}$ Crimes Act 1961, s 123.

${ }^{14}$ Rex T Hadar "The Right to Protection of Religious Feelings" (2008) 11(4) Otago LR. 629.
} 
take into account the repudiation of views previously expressed insofar as it suggests that the speaker has disavowed their hateful opinions.

That community tension or division may be created by the presence of the individual within the country should not be a grounds for denying entry where the likely actions of the alien to create this tension would fall short of a criminal offense, except in extreme circumstances. Denying entry to a speaker intending to engage in lawful behaviour could perhaps be justified where the direct result of entry would be a violent reaction which could not be controlled without an extraordinary response, for example wide scale rioting responded to by the use of emergency police powers.

This is firstly because it is too easy to characterise robust and necessary debate within the ambit of the amorphous harm of 'division' or threats to the harmony of the community. Even if the presence of a person in a country can cause harm of this nature, that suggests deeper underlying issues that are not being addressed due to lack of discussion so the promotion of discussion may be in the public interest in the long run. It is very unlikely for example that the brief visit of a prominent Holocaust denier in a non-European country with a Jewish community would lead to any major unrest unless there were pre-existing issues of anti-Semitism.

It needs to be remembered that all sorts of groups engage in the types of political protest which could be characterised as disruptive or even involves violent. These rarely tear apart the fabric of our society, and it would be wrong to shut down discourse in order to avoid them. Student led protests against the government of the day ${ }^{15}$ have a proud tradition of

${ }^{15}$ Neil Reid "Protests Blamed on Bill English" (3 June 2012) Stuff < www.stuff.co.nz $>$. 
disruption, as do protests by the anti-globalisation movement ${ }^{16}$ and the recent Occupy movement. ${ }^{17}$ In these cases the protest was not set off by hate or division, but by reasonable disagreements about social and economic policy. If immigration rules could justify banning an international anti-globalisation leader, or alternatively a figure passionately resented by a movement whose visit would lead to protests they have the potential to chill this kind of important discourse.

Secondly because this effectively creates a 'hecklers veto' on debate. Groups can place pressure on the government to quash speech they oppose by threatening to engage in the very type of action that the government intends to deter. A hecklers veto enshrined in immigration law but not in domestic law regulating speech creates a distinction between the speech of citizens and aliens which cannot be justified on non-arbitrary grounds. Whilst it can be said that the state has no responsibility to protect the free speech rights of an alien, it is not done for that purpose. Government ought to protect the rights of its own citizens who want to listen to the views of those outside their borders, even if those views are fringe or contain elements of what we might consider to be objective harmful speech.

It is not necessarily only the hateful who wish to listen to controversial speakers. Often controversial speakers will be invited to neutral or ideologically opposed forums in order to encourage debate. See for example Iranian President Mahmoud Ahmadinejad's (notorious for Holocaust denial, anti-Semitic views and homophobic views) invitation to

\footnotetext{
${ }^{16}$ Noah Smith "The Dark Side of Globalization: Why Seattle's 1999 Protesters Were Right" (6 January 2014) The Atlantic <www.theatlantic.com>.

17 "Violent clashes between Occupy Wall Street protesters and police in New York" (17 November 2011) The Telegraph <www.telegraph.co.uk>.
} 
speak at Columbia University in 2007. ${ }^{18}$ When David Irving was invited to speak in New Zealand it was not by a neo-Nazi or anti-Semitic group, but by the National Press Club. ${ }^{19}$ The legitimacy of the grievances held by hecklers may also be questionable. For example while we would have considerable sympathy for Holocaust survivors objecting to the visit of a prominent Holocaust denier, the same sympathy may not be extended to radical elements of religious groups who seek to violently protest provocative criticism of their religion, whether that religious group is a majority or a minority. The decision maker can only distinguishing between those types of community division by making judgements which go purely to the value of the content of that speech or the legitimacy of anger expressed by a certain group. This creates vast discretion for the decision maker to censor speech on the basis of their own personal view or to enforce the views of the majority upon the minority, when protecting unpopular speech should be the very essence of protecting freedom of expression.

18 "Ahmadinejad Blasts Israel, Denies Existence of Iranian Gays During Columbia Speech" (24 September 2007) Fox News <www.foxnews.com>.

19 "Lawyer bids to get David Irving let in to NZ" (16 September 2004) NZ Herald <www.nzherald.co.nz>. 


\section{Freedom Of Expression And Freedom Of Movement In The United Kingdom}

\section{A Human Rights And Immigration Framework \\ 1 Introduction}

The ethos of English human rights law stems from the constitutional arrangements of the United Kingdom. The lack of a written constitution leaves the process of protecting rights primarily to a set of evolving and flexible constitutional conventions and principles which are applied by the courts. Although the lack of protections of human rights through the existence of 'supreme law' may leave human rights constitutionally vulnerable, most often the Parliament has been supportive of the human rights project through the passage of various statutes.

The strength of this approach is its malleability, English courts have been able to adopt European human rights law and England's broader international law obligations into the English law through the use of statutory interpretation and the standards set in judicial review.

Many explanations of the role human rights play under English law will begin by explaining its theoretical underpinnings or historical context by examining historical documents like the Magna Carta and the Bill of Rights 1688. Whilst these are significant milestones in legal philosophy and history, the simplest explanation for these purposes is start from the European Convention on Human Rights (ECHR), and go on to examine the most directly relevant statute, the Human Rights Act 1998. 


\section{European Convention On Human Rights And European Integration}

The modern European project was conceived in the wake of World War II. The devastation in Europe created by wars in the preceding 40 years lead to the perception of a greater need for a unified Europe, which was seen as a project to be pursued on a legal, social and economic level. ${ }^{2021}$ The ECHR is also part of the broader human rights project that emerged after 1945 following the creation of the Universal Declaration of Human Rights (UNHR) and the Forth Geneva Convention, which came into existence in 1948 and 1949 respectively. ${ }^{22}$

Despite the United Kingdom playing a part in the drafting of the ECHR, its integration into the broader English legal framework was gradual. The initial position was that, like other treaties, it required the adoption in statute in order to be considered part of the domestic law. In 1965 individuals were given the right to petition the European Court of Human Rights under the convention. ${ }^{23}$ Over time common law developed to enable treaties to be used as interpretative aids in the process of statutory interpretation. $R v$ Secretary of State for the Home Department Ex parte Brind [1991] finds that where there are two available interpretations of a statutory provision, the interpretation which gives effect to a convention right is to be preferred. This is because Parliament is to be presumed to have legislated with the intention of complying with treaty rights.

\footnotetext{
${ }^{20} \mathrm{H}$ Barnett Constitutional and Administrative Law ( $8^{\text {th }}$ ed, Routledge, Oxon, 2011) at 497.

${ }^{21}$ It's hard not to be struck by the sentimentality expressed by the drafters of the foundational documents of the new international order post World War Two, something rarely seen in more recent treaties. The preamble UN Charter, for example, begins with the famous line "We the peoples of the United Nations determined to save succeeding generations from the scourge of war, which twice in our lifetime has brought untold sorrow to mankind".

22 The preamble to the ECHR refers to the UNDR.

${ }^{23}$ Barnett "Constitutional and Administrative Law", above n 20, at 497
} 
Article 10 covers the Freedom of Expression: ${ }^{24}$

1. Everyone has the right to freedom of expression. This right shall include freedom to hold opinions and to receive and impart information and ideas without interference by public authority and regardless of frontiers. This Article shall not prevent States from requiring the licensing of broadcasting, television or cinema enterprises.

2. The exercise of these freedoms, since it carries with it duties and responsibilities, may be subject to such formalities, conditions, restrictions or penalties as are prescribed by law and are necessary in a democratic society, in the interests of national security, territorial integrity or public safety, for the prevention of disorder or crime, for the protection of health or morals, for the protection of the reputation or rights of others, for preventing the disclosure of information received in confidence, or for maintaining the authority and impartiality of the judiciary

\section{Human Rights Act 1998}

The Human Rights Act 1998 substantively codifies and gives affect to convention rights under English domestic law, making the ECHR the centrepiece of English human rights law. Sections one and two lay out which parts of the convention are brought within English law and the affect that this has. Section 1(1)-(2) reads: ${ }^{25}$

\footnotetext{
${ }^{24}$ European Convention on Human Rights ETS 5 (signed 4 November 1950, entered into force 3 September 1953), Article 10.

${ }^{25}$ Human Rights Act 1998, s 1 (UK).
} 


\section{The Convention Rights.}

(1) In this Act "the Convention rights" means the rights and fundamental freedoms set out in-

(a) Articles 2 to 12 and 14 of the Convention,

(b) Articles 1 to 3 of the First Protocol, and

(c) Article 1 of the Thirteenth Protocol, as read with Articles 16 to 18 of the Convention.

(2)Those Articles are to have effect for the purposes of this Act subject to any designated derogation or reservation (as to which see sections 14 and 15).

This incorporates most but not all key rights within the convention. Article 13, which is omitted is the right to an effective remedy. The United Kingdom also currently has a reservation with respect to Article 2 of the first protocol, accepting the principle of the right to an education "only so far as it is compatible with the provision of efficient instruction and training, and the avoidance of unreasonable public expenditure." 26

Sections 3 and 6(1) set out the primary ways in which the Act enforces the convention rights: ${ }^{27}$

\section{Interpretation of legislation}

(1)So far as it is possible to do so, primary legislation and subordinate legislation must be read and given effect in a way which is compatible with the Convention rights.

\section{Acts of public authorities}

\footnotetext{
${ }^{26}$ Schedule 3.

${ }^{27}$ Section 3.
} 
(1)It is unlawful for a public authority to act in a way which is incompatible with a Convention right.

This incorporates the common law position set out above, and is the operative provision for the courts to invalidate secondary legislation which is incompatible with convention rights. Note that it is also very similar to other statutory provisions such as s 6 the New Zealand Bill of Rights Act 1990.

Sections 4 and 6 deal with cases where the primary legislation is incompatible with a convention right. In those circumstances the courts may make a declaration to that effect under s 4. However under s 6(2) the courts will neither strike out secondary legislation nor overturn the actions of a public authority if it is required to act in a way that is incompatible with the convention. ${ }^{28}$ Section 6(3) goes on to define 'public authority'.

\section{Immigration Rules}

Section 1 of the Immigration Act $1971^{29}$ empowers the United Kingdom government to make regulations to control the entry of persons into the United Kingdom. Within those regulations is set out the grounds under which the Home Secretary may refuse leave to enter the United Kingdom. Rule 320(6) provides that leave may be refused:

"Where the Secretary of State has personally directed that the exclusion of a person from the United Kingdom is conducive to the public good.”

\footnotetext{
${ }^{28}$ Section 6

${ }^{29}$ Immigration Act 1971 (UK).
} 
While there exists a specialised immigration appeals process for decisions where the Home Secretary refuses leave, it specifically exclude decisions where the decisions is based on rule 320(6). However these decisions are still reviewable under the normal principles of judicial review.

\section{B Farrakhan $v$ Secretary of State for the Home Department}

\section{Background}

Louis Farrakhan is the head of the Nation of Islam, a predominantly African American political/religious movement which has been accused of radicalism and promoting antiSemitism. ${ }^{30}$ Farrakhan has personally been accused of promoting anti-Semitism on several occasions. ${ }^{31}$ Specifically within the United Kingdom, members of the Nation of Islam were involved in violent clashes with police outside an inquiry into the police investigation of the racially motivated murder of Stephen Lawrence. ${ }^{32}$

Mr Farrakhan had been planning to visit the United Kingdom for a number of years and had a history of communications with the Home Secretary and officials with regards to his eligibility to enter the United Kingdom. On 20 November 2000 the Home Secretary sent Mr Farrakhan a letter informing him of his decision to exclude Mr Farrakhan from the United Kingdom. Farrakhan applied for judicial review of that decision, and his application was successful at the Court of Queen's Bench, with the decision pronounced on 31 July

\footnotetext{
30 "What is the Nation of Islam" Anti-Defamation League <www.adl.org>.

${ }^{31} R$. (on the application of Farrakhan) v Secretary of State for the Home Department [2002] 3 W.L.R. 481 at [20].

32 "Violence disrupts Lawrence Inquiry" (29 June 1998) BBC <www.bbc.co.uk>.
} 
2001 and handed down on 1 October $2011 .^{33}$ The Home Secretary appealed to the Court of Appeal.

\section{Decision}

It was not at issue that, prima facie, the Home Secretary had the right to exclude $\mathrm{Mr}$ Farrakhan from the United Kingdom under the Immigration Act 1971. However if the decision violates Article 10 of the convention then it can be overturned. It must first be established that the convention applies to decisions in an immigration context.

The Court observes that the issue rarely arises in an immigration context. However in one European Court of Human Rights case a German Member of the European Parliament was able to successfully challenge a decision to exclude him from New Caledonia, having recently visited French Polynesia and campaigned against French nuclear testing and the French presence in the Pacific. ${ }^{34}$ The Court expresses a desire to limit the extensiveness of this right in this context. It concludes that Article 10 will apply "where the authorities of a State refuse entry or expel an alien from its territory solely for the purpose of preventing the alien from exercising a Convention right within the territory, or by way of sanction for the exercise of a Convention right."

The next issue is the approach that the Court should take to judicial review. The Court states that the Wednesbury ${ }^{35}$ approach is not the correct approach in applying the Convention, rather the margin of appreciation approach should be used. ${ }^{36}$ This generally allows for closer review than the Wednesbury test. Article 10.2 makes it clear that the right

\footnotetext{
${ }^{33}$ Farrakhan $v$ Secretary of State for the Home Department [2001] EWHC admin 781.

${ }^{34}$ Piermont v France (1995) 20 EHRR 301 (ECHR)

${ }^{35}$ Picture Houses Ltd v Wednesbury Corporation [1948] 1 KB 223.

${ }^{36}$ Above at n 31, at [64].
} 
in Article 10.1 are not absolute. In order to decide whether a restriction is justified, the Court applies the doctrine of proportionality where it looks at the rights at play and the factors in the particular case to decide how wide a margin of appreciation is afforded to the decision maker. The wider the margin of appreciation, the less onerous the obligation on the decision maker to justify the breach of the right.

The Court decides that the case is appropriate for a wide margin of appreciation for several reasons. Firstly because the immigration context is one where greater autonomy is granted to decision makers. ${ }^{37}$ Secondly because the Home Secretary is a better actor than the Court to make decisions. The Secretary is democratically accountable, has more expertise and access to more relevant information. ${ }^{38}$ The decision is also considered a proportionate restriction upon Mr Farrakhan's right to freedom of expression because all he has been denied is a particular forum to express his views, he is still free to promote his views in the United Kingdom in other ways. ${ }^{39}$ In coming to this decision the Court of Appeal chides Turner J's approach of requiring the Home Secretary to demonstrate "substantial objective justification" for the decision to stand, arguing that this constitutes the judge substituting his judgment for that of the decision maker. ${ }^{40}$

\section{Analysis}

The Court's approach to whether Article 10 applies is confusing. Lord Philips firstly claims that it is conceded by the Home Secretary in submissions that Article 10 is engaged in this

\footnotetext{
37 At [71].

${ }^{38}$ At [73].

${ }^{39}$ At [77].

${ }^{40}$ At [76].
} 
case and that they have "proceeded on the basis of that concession without examining whether or not it is correctly made". ${ }^{41}$ The Court then embarks on a discussion of Strasbourg jurisprudence concerning the applicability of the Convention to immigration cases. Whilst there are very few cases concerning Article 10 on this point, other immigration cases clearly establish that Article 8 (the right to respect for private and family life) applies to aliens where Article 8 rights are violated. ${ }^{42}$

This still begs the question of which immigration cases engage Article 10. The Court is initially quite restrictive on this point, claiming that Article 10 is engaged where authorities refuse entry or expel an alien "solely for the purpose of preventing the alien from exercising a Convention right within the territory, or by of sanction for the exercise of a Convention right". ${ }^{43}$ To what extent the Court makes the determination of the basis of the decision is left open, however it expresses a willingness to defer to the decision makers stated reasons for the decision rather than enunciate the extent to which it can examine those stated reasons. $^{44}$

Again the Court appears to fudge its answer to the question in this case. It acknowledges that preventing Mr Farrakhan from expressing his views was not the "primary object" of his exclusion, but that it was merely "one object" of his exclusion. ${ }^{45}$ However the Court then asserts that this is sufficient to bring Article 10 into play. Unless the "purpose" of the decision and the "object" of the decision mean two different things, it is difficult to

\footnotetext{
${ }^{41}$ Above at 31, at [34].

${ }^{42}$ At [38].

${ }^{43}$ At [55].

${ }^{44}$ At [58].

${ }^{45}$ At [62].
} 
reconcile the Courts statement of the principle of law in paragraph 55 and its application of that principle in paragraph 62.

Aside from the court's own contradictions, there are two problems with the approach taken. Firstly it could present problems for executive accountability. The decision maker could frame the grounds of their decision as being outside where the court draws the line of application for Article 10 once that line is made clear. Too often, restrictions on speech are justified on the basis of protecting national security or other amorphous public interests. If the Court agrees to grant a large amount of deference as to whether the right freedom of expression is engaged in the first place, it will be abdicating its duty to protect human rights.

Secondly, even if the Court should accept any justification for a decision at face value, the justification presented here clearly should not remove freedom of expression as an issue. The Court accepts that the basis of the decision was the "risk that his presence in this country might provide a catalyst for disorder", and that this may somehow bring the issue outside of the realm of freedom of expression. The type of disorder envisioned is based upon a single incident where three protestors from the Nation of Islam was arrested while protesting outside an inquest into the death of teenager Stephen Lawrence. They were charged with minor offenses. While this was no doubt disorderly it also occurred in the context of a protest about a legitimate issue for a disenfranchised minority. Even if an isolated incident is sufficient evidence that Mr Farrakhan's visit will provoke disorder, the basic question that is never asked was: Is the Secretary entitled to conclude, as a matter of law, that excluding Mr Farrakhan to prevent a repeat of this type of act is in the public good? An assessment based upon an understanding of the importance of freedom of 
expression and the constitutional protections of freedom of expression may well have concluded that he was not.

There are reasons to believe that Mr Farrakhan's speech deserves particular protection. The Court of Appeal saw Mr Farrakhan as a harmful voice in social discourse, it seemed incapable of looking past Mr Farrakhan's anti-Semitic comments to the wider social context of his visit. Black communities in the United Kingdom are a disenfranchised minority. They are poorer ${ }^{46}$, more unemployed,${ }^{47}$ less likely to vote, ${ }^{48}$ underrepresented in Parliament ${ }^{49}$ and more likely to be discriminated against in the criminal justice system. ${ }^{50}$ Why might protests outside the Stephen Lawrence inquest have turned violent? In 1993 Lawrence died of stab wounds in a racially motivated murder while waiting at a bus stop. Five suspects were tried and acquitted. The inquest into the murder found that officers investigating the murder had been "incompetent" and that the Metropolitan Police were "institutionally racist". ${ }^{51}$ It should be no surprise that these issues create profound institutional distrust between the government and minority groups, and that this sense of hopelessness may lead to violent protest.

That these groups feel they cannot resolve these issues through democratic processes should reflect poorly on those democratic processes as much as it does on those who

\footnotetext{
${ }^{46}$ Guy Palmer "Poverty Rates among Ethnic Groups in Great Britain" (30 April 2007) Joseph Rowntree Foundation <www.jrf.org.uk>.

${ }^{47}$ Randeep Ramesh "Black people more likely to be jobless in Britain than US, research reveals" (13 April 2012) The Guardian <www.guardian.co.uk>

48 Tim Wigmore "Why don't more ethnic minorities vote?" (21 March 2014) The Telegraph <www.telegraph.co.uk>.

49 Rajeev Syal "Parliament failing to represent UKs ethnic diversity" (31 July 2014) The Guardian <www.guardian.co.uk>.

${ }^{50}$ Vikram Dodd "Racism 'rife in the justice system"” (20 March 2000) The Guardian <www.guardian.co.uk>.

${ }^{51}$ Home Office "Report of the Stephen Lawrence Inquiry" (24 February 1999) UK Government <www.gov.uk>.
} 
commit disorderly acts at protests. In order to defend the rights of these minorities, the Court needs to be even more strenuous about protecting their expression, especially since officials accountable through the traditional democratic channels that fail minorities are less likely to take their interests into account. To take the symbolic act of denouncing Farrakhan by excluding him from the country risks being seen as a further form of oppression, which may be more likely to lead to disorder than his visit. It risks binge seen as the very silencing of minorities that hate speech laws are intended to prevent. Turner $\mathrm{J}$ to his credit does consider the disadvantage as a factor in his decision. ${ }^{52}$

The other possible kind of disorder possibility considered by the Secretary is that public meetings hosted by Mr Farrakhan will lead to disorderly responses by those who disagree with him. If this is the case, then the hecklers veto is being invoked to deny Mr Farrakhan entry. It is disappointing that the freedom of expression implications of issue are not raised by the Court of Appeal.

The grounds given to justify a wider margin of appreciation merit a further look. It shouldn't be ignored that the Court is not the decision maker, its role is to review the decision rather than remake it based on the merits of the decision. There is a philosophical battle between the concepts of deference and the 'hard look' approach, and which approach to take requires a subjective assessment based on the circumstances. ${ }^{53}$ However in my assessment the Court is too deferential to the decision maker in this case. The Court suggests that because the decision maker is democratically accountable their decisions warrant less scrutiny. But this ignores the difference between democracy and human rights.

\footnotetext{
52 At [44].

${ }^{53}$ Aileen Kavanagh "Defending deference in public law and constitutional theory" (2010) 126 L.Q.R. 222 at 224.
} 
Democracy is not necessarily capable of protecting rights when the rights concerned are those of a minority. The judiciary ought to regard itself as the guardian of rights in a democratic society, it is the only institution capable of doing so in cases of this nature. Judicial power is not necessarily a usurping of executive authority when that power has been given to it by Parliament through legislation such as the Human Rights Act 1998 .

\section{Naik v Secretary of State for the Home Department \\ 1 Background}

Dr Naik is an Indian Muslim personality of considerable influence due to his work as a public speaker, 'spiritual guru', community leader and author. He was ranked as one of the top ten spiritual gurus in India in 2010 and top 100 most influential people in India. ${ }^{54} \mathrm{He}$ had been a regular visitor to the United Kingdom since 1990, making several public speeches at Islamic events. ${ }^{55}$

Naik has been accused of sympathizing with and promoting terrorism. Among his controversial statements he has made comments in public forums sympathetic to the cause of Osama Bin Laden saying that he is "fighting the enemies of Islam" while also saying that he does not condone violence against innocent people. He has promoted September 11 conspiracy theories and the belief that "America is controlled by the Jews."

In mid June 2010 he planned to speak at a major event at Wembley Stadium expected to attract as many as 45,000 people. The planned visit received attention from tabloid

${ }^{54} R$. (on the application of Naik) $v$ Secretary of State for the Home Department [2010] EWHC 2825 (Ch) at [2]

${ }^{55}$ At [3].

${ }^{56}$ At [4] 
newspapers on 30 May 2010 where a story ran under the headline "Muslim preacher of hate is let into Britain". 57

In response Dr Naik's representatives met with officials from the Home Office asserting that Dr Naik intended to promote a message of peace based on Islamic values on his speaking tour and that he had spoken out against terrorist attacks such as $9 / 11$. However on $16^{\text {th }}$ June, two days before his scheduled arrival, the Home Secretary made the decision to exclude him. A letter sent on $17^{\text {th }}$ June informed Naik that he was to be excluded "for engaging in unacceptable behaviour by making statements that attempt to justify terrorist activity and fostering hatred"58 and that his visa was being revoked on grounds that it was "conducive to the public good". Several days later Dr Naik took judicial review proceedings. He was unsuccessful at the Court of Queen's Bench, however the Court of Appeal agreed to hear the case.

\section{Decision}

In considering the applicability of Article 10 to aliens, the original Court held that the decision in Farrakhan was not binding and relied on other Strasbourg authority to suggest that Article 10 was territorially limited. ${ }^{59}$ The judge however concluded that Dr Naik's supporters who wished to see him in the United Kingdom could rely on Article 10 as their freedom of expression was curtailed by being denied the ability to see Dr Naik, while not ruling on the question of whether Naik could rely on Article $10 .^{60}$

\footnotetext{
${ }^{57}$ At [11]

${ }^{58}$ Above at 54, at [8].

${ }^{59} R$. (on the application of Naik) v Secretary of State for the Home Department [2011] EWCA Civ 1546 (CA) at [26].

${ }^{60}$ At [32].
} 
The Court of Appeal struggled on this point because the authorities which examined the limits of Article 10 were not always consistent. Counsel for the Home Secretary attempted to distinguish one case on the grounds that the applicant was physically present in the country when the judicial review application was made. ${ }^{61}$ However the Court concluded this approach would be unfair since it would disadvantage visitors who took the reasonable step to apply for a visa before arriving in the country. ${ }^{62}$

The approach in Naik differs from Farrakhan in that it ignores whether the decision maker's stated reasons for exclusion directly relate to freedom of expression. Once the applicability of Article 10 is established and the Court accepts that freedom of expression is curtailed, it is assumed that the decision is reviewable under Article $10 .{ }^{63}$

The judge takes a different approach to Farrakhan in applying the proportionality test, viewing Farrakhan as outdated. ${ }^{64}$ Instead of looking at various factors which could limit or widen the margin of appreciation the Court compares the extent to which it could differ to the decision maker on the content of the issue concerned to the importance of the Court's role in acting as a 'guardian of human rights'. ${ }^{65}$ In weighing these up it concludes that the Court is required to satisfy itself that rights intrusion is proportionate to the legitimate purpose, and that the reasons given for the exclusion were relevant and sufficient. ${ }^{66}$

On the issue of proportionality, the Court rejects the logic in Farrakhan that the intrusion into human rights in an immigration context is lessened because the applicant is only being

\footnotetext{
${ }^{61}$ At [30].

${ }^{62}$ At [32].

${ }^{63}$ At [48]

${ }^{64}$ At [37].

${ }^{65}$ At [64].

${ }^{66}$ At [64].
} 
denied a forum rather than the opportunity to express their views at all. This is irrelevant to the proportionality question, since by its own logic the benefit of promoting the public good is also reduced if the applicant can speak in other ways ${ }^{67}$ It also ignores the symbolic relevance of the decision itself as a public act of condemning a particular form of speech. ${ }^{68}$ In the end, the issue which the judges seems to find most decisive is one not raised in Farrakhan. Following the London bombings of July $7^{\text {th }} 2005$ the Home Secretary adopted a new policy of exclusion based on a list of unacceptable behaviours including expressing views which "foment, justify or glorify terrorist violence in furtherance of particular beliefs" or "foster hatred which might lead to inter-community violence in the UK", and the decision is founded on this policy. ${ }^{69}$ Carnwath LJ devises a three part test for deciding whether a decision made according to the policy is reviewable: ${ }^{70}$

“(1) had Dr Naik engaged in the types of behaviour listed in the August 2005 statement?

(2) if so, had he not only repudiated such views, but demonstrated publicly that he had done so? (3) would his exclusion under the policy be proportionate in relation to its legitimate aims?"

The judges are persuaded that the reduced discretion inherent in applying this policy, combined with the fact that the legitimacy of the policy is not itself challenged makes the decision more legitimate. On the first question it is found that the behaviour clearly violates the policy, the qualifiers on his statements endorsing terrorism were not sufficient. On the

\footnotetext{
67 At [66].

${ }^{68}$ At [67].

${ }^{69}$ At [65].

${ }^{70}$ At [68].
} 
second Carnwath LJ acknowledges that while Naik has provided strong evidence including witness statements that his general message is a peaceful one, he has not fulfilled the terms of the policy to specifically repudiate statements where he appears to support terrorism. On the question of proportionality it is agreed that the goal of protecting national security is sufficiently important to justify the limitation on expression. ${ }^{71}$

\section{Analysis}

The issue raised in this case which distinguishes it from other similar cases concerning freedom of movement and expression in that it more clearly falls within a national security context because the controversial statements involved concern the promotion of terrorism. National security considerations seem very different to considerations related to ‘community disharmony' or 'division'. Where the perceived harms from those issues derives from expression occurring within the realm of democratic debate or a market of ideas, the harm from the promotion of terrorism is far more tangible and substantial.

After the events of September 112001 , balancing the needs of national security with human rights has become a heightened theme in public debate. The most significant post 9/11 case in the United Kingdom balancing these rights and concerns is A and others $v$ Secretary of State for the Home Department. ${ }^{72}$ The case concerned the detention without trial of foreign terrorist suspects under the now repealed Anti-Terrorism Crime and Security Act $2001 .^{73}$ The government acknowledged that the policy violated human rights and sought a derogation under s 1(2) of the Human Rights Act 1998. According to the majority the

\footnotetext{
${ }^{71}$ At [74]

${ }^{72} A$ and others $v$ Secretary of State for the Home Department [2005] 2 AC 58 (HL).

${ }^{73}$ Steve Foster "The fight against terrorism, detention without trial and human rights" (2009) 14(1) Cov.L.J. 4 at 4.
} 
policy failed the proportionality test. Because the policy discriminated between foreign nationals and citizens it could not be shown to be necessary for national security. ${ }^{74}$

The approach advocated in $A$ is for the role of the court as a protector of human rights and against the philosophy of judicial deference on questions of human rights, even though substantial weight is given to the executive's judgment on what measures are needed to protect national security. Although in Naik the judges are at pains to point out that they are not substituting the decision of the Home Secretary for their own, ${ }^{75}$ it is clear that they do not adopt a policy of judicial deference. Ensuring that the standard of review is that evidence considered by the decision maker is "relevant and sufficient" is a significant departure from Farrakhan, where no real attempt is made to review the strength of the evidence presented by the Home Secretary.

A further blow to the Farrakhan decision is the judgment rejecting the argument that the rights abrogation is not significant because restricting movement only denies the speaker a forum. According to Carnwath LJ this holds little weight in a proportionality analysis, firstly because it also shows that there are limited benefits to excluding the applicant, and because the decision to exclude also carries symbolic value. ${ }^{76}$ Recall that this was a significant part of the proportionality analysis in Farrakhan.

The way the case is decided by Carnwath LJ still raises questions. Firstly, he appears to place great weight on the fact that the unacceptable behaviours policy itself is not being challenged as violating convention rights, only the application of it. ${ }^{77}$ It would have been

\footnotetext{
${ }^{74}$ Foster "The fight against terrorism, detention without trial and human rights", above at 73 , at 7.

${ }^{75}$ At [64]

${ }^{76}$ At [66]

${ }^{77}$ At [73]
} 
interesting to discuss to what extent the policy violates Article 10 nonetheless. The relevant section of the policy provides: ${ }^{78}$

3. The list of unacceptable behaviours is indicative rather than exhaustive. It covers any non-UK national whether in the UK or abroad who uses any means or medium including:

- Writing, producing or distributing material;

- Public speaking including preaching

- Running a website; or

- Using a position of responsibility such as teacher, community or youth leader

To express views which:

- Foment, justify or glorify terrorist violence in furtherance of particular beliefs;

- Seek to provoke others to terrorist acts;

- Foment other serious criminal activity or seek to provoke others to serious criminal acts or;

- Foster hatred which might lead to inter-community violence in the UK."

On its face the policy does restrict freedom of expression. Furthermore it could fail the proportionality test for the same reason the policy in $A$ failed: it discriminates between foreign nationals and citizens. However as suggested by Cranston $\mathrm{J}$ in the decision on appeal the rights limitation may be justified under article $10(2) .{ }^{79}$ The policy struck down in $A$ was a vastly more abhorrent abrogation of rights.

The logic used by Carnwath LJ to judge the application of the policy may be questionable. At various points the judge lauds the flexibility of the policy which provides "an indicative

\footnotetext{
${ }_{78}$ At [15]
}

${ }^{79}$ At $[80]$ 
rather than exhaustive list" of excludable behaviours and acknowledges that the stated reasons for exclusion are "a legitimate extension of the spirit of the policy". ${ }^{80}$ If this is the case then it is questionable whether the policy is limiting the "undefined, general discretion" of the Home Secretary that the Court opposes in a way that makes their decision more legitimate. ${ }^{81}$

\section{Geert Wilders Case}

\section{Background}

Geert Wilders is a Dutch Member of Parliament, and the leader of the Partij voor de Vrijheid or Party for Freedom (PVV). The PVV is generally characterised as a right wing or far right wing populist party. It opposes immigration and is anti-Islamic. In 2009 the PVV was the $5^{\text {th }}$ largest party in terms of seats in the Tweede Kamer der Staten-Generaal (lower house). At the subsequent elections in 2010 it became the $3^{\text {rd }}$ largest party, demonstrating a rich vein of support for its leader and ideology in the Netherlands.

Wilders is most controversial for his statements about Islam, saying that "Islam not as a religion, but a dangerous, totalitarian ideology, equal to communism and fascism. ${ }^{82} \mathrm{He}$ has argued that there is "no such thing as moderate Islam", that the Koran is "a book of war" stated that "Islam is a threat to Western civilisation and Dutch culture." 83 In 2008 Wilders produced a short film, Fitna, about the Koran, terrorism, and Islam in the

\footnotetext{
${ }^{80}$ At [65]

${ }^{81}$ At [65]

82 "Geert Wilders: Man out of Time" (26 January 2009) Assyrian International News Agency <www.aina.org>.

83 "Mr Wilder's contribution to the parliamentary debate on Islamic activism" (29 September 2007) Geert Wilders Web Blog <www.geertwilders.nl>.
} 
Netherlands. ${ }^{84}$ Wilders then conducted the "Facing Jihad World Tour" showing the film in various countries such as the United States.

Wilders was invited to show the film in the House of Lords by Baroness Cox and Lord Pearson on 12 February 2009. On 10 February he received a letter from the Secretary of State for the Home Department informing him that he would not be allowed entry to the United Kingdom. He chose to travel to London Heathrow Airport anyway, where he was met by an immigration official and refused entry under regulation 21 of the Immigration (European Economic Area Regulations) 2006. Wilders appealed to the Asylum and Immigration Tribunal.

\section{Tribunal Decision}

The European Economic Area provides for a greater freedom of movement between countries than would normally exist under the Immigration Act 1971. Below is a brief guide through the relevant regulations which permit entry to European citizens and allow exclusion in limited circumstances: ${ }^{858687}$

\section{Regulation 11(1)}

"An EEA National must be admitted to the UK if he produces on arrival a valid national identity card or passport issued by an EEA state."

\section{Regulation 19}

\footnotetext{
84 "Dutch anti-Muslim politician Geert Wilders to screen Fitna film in Washington" (24 February 2009) The Telegraph <www.telegraph.co.uk>.

${ }^{85}$ GW (EEA reg: 21: 'fundamental interests') Netherlands [2009] UKAIT 00050, at [8].

${ }^{86}$ At [9]

${ }^{87}$ At [11]
} 
"A person is not entitled to be admitted to the UK by virtue of Regulation 11 if his exclusion is justified on grounds of public policy, public security or public health in accordance with Regulation 21."

\section{Regulation 21}

(1) In this regulation a 'relevant decision' means an EEA decision taken on the grounds of public policy, public security or public health.

(2) A relevant decision may not be taken to serve economic ends.

(5) Where a relevant decision is taken on the grounds of public policy or public security it shall, in addition to complying with the preceding paragraphs of this regulation, be taken in accordance with the following principles:

(a) the decision must comply with the principle of proportionality.

(b) the decision must be based exclusively on the personal conduct of the person concerned.

(c) the personal conduct of the person concerned must represent a genuine, present, and sufficiently serious threat affecting one of the fundamental interests of society.

(d) matters isolated from the particulars of the case or which relate to considerations of general prevention do not justify the decision.

(e) a person's previous criminal convictions do not in themselves justify the decision".

Recall Article 10 of the ECHR, which is also relevant to the decision.

The Tribunal had to consider what would constitute a "threat affecting one of the fundamental interests of society". It concluded that any likely actions taken by Mr Wilders that would be neither unlawful nor prohibited (a breach of the peace being prohibited but 
not unlawful) could not constitute such a threat, as the function of the law was to protect the fundamental interests of society. ${ }^{88}$

The Tribunal then turned to the potential offences which Mr Wilders may commit while in the United Kingdom. The only one considered relevant was s 5 of the Public Order Act 1986 which reads: ${ }^{89}$

\section{Section 5}

(1) A person is guilty of an offence if he:

(a) uses threatening, abusive or insulting words or behaviour, or disorderly behaviour, or

(b) displays any writing, sign or other visible representation which is threatening, abusive or insulting,

within the hearing or sight of a person likely to be caused harassment, alarm or distress thereby.

The Tribunal considered the Secretaries judgment that denial of access was justified under regulation $21(5)(c)$ to be deeply flawed. In the first place it appeared to be based on the understanding that a threat to "community harmony" constituted a threat to public security and would therefore justify exclusion. ${ }^{90}$ It found that the Secretary had presented no evidence of the type of threat Mr Wilders presented, and that no such evidence existed. That Mr Wilders had visited the United Kingdom and other European countries previously and that his film was widely available in the United Kingdom without causing and public

\footnotetext{
${ }^{88}$ At [16].

${ }^{89}$ Public Order Act 1986, s 5 (UK).

${ }^{90}$ At [5].
} 
order difficulty were taken into account by the Tribunal. ${ }^{91}$ The Tribunal also dismissed the fact that Mr Wilders was being prosecuted in the Netherlands for charges relating to public order as irrelevant because those charges had not been proven.

The Tribunal made two distinctions between this case and Farrakhan. Firstly that as a Dutch citizen Mr Wilders was entitled to an underlying right to entry into the United Kingdom where Mr Farrakhan as a United States citizen was not. ${ }^{92}$ Secondly that $\mathrm{Mr}$ Wilders intended to speak to parliamentarians and hold an open question and answer session, where as Mr Farrakhan mainly intended to hold private meetings with his followers..$^{93}$

\section{Analysis}

It is worth exploring the justification for distinguishing between Farrakhan and this case. As stated above the Tribunal gives two reasons. The first is that Farrakhan is a United States citizen and thus does not have the same 'underlying right' to enter the United Kingdom that a Dutch citizen does. The judgement places great emphasis on European citizenship being a crucial protection for Wilders freedom of expression. It is said that this underlying right increases the standard of review, so that a smaller abrogation of free expression is required to rule in Wilders favour. To some extent this reflects the philosophy behind immigration law: aliens are not citizens and their rights are subject to the whim of the state. But different classes of people who are not citizens are commonly given rights

\footnotetext{
${ }^{91}$ At [28].

${ }^{92}$ At [43].

${ }^{93}$ At [46].
} 
short of citizenship. The European Economic Area provides European citizens with quasicitizenship rights in respect of immigration.

Regulation 11(1) appears to be the basis for this underlying right. However regulation 11(1) is ultimately subject to regulations 19 and 21 so needs to read in this light. Rule 21 appears to be designed with similar language to rule 320(6). One grants the right to exclude on the basis of the 'public good', the other on the basis of 'public policy, public security or public health.' Rule 21 in the European regulations is qualified in two main respects: Firstly the decision must be based exclusively on the personal conduct of the individual. Secondly this must violate a 'fundamental interest' in society. Beyond applying these rules as they were intended there seems little reason to suppose that the 'underlying right' entitles Wilders to a more thorough review than anyone else. It was established in Farrakhan that the right to freedom of expression exists primarily to benefit the followers of Mr Farrakhan who are British citizens. They should not have lesser rights under the ECHR because the person they wish to listen to is not European.

The second reason given to distinguish between the cases is that Wilders intended expression might "inform the votes of voters as well as the laws of lawmakers and the policy of policy makers" and that this was significant because "freedom of speech in a democratic society is one of the ways that democracy works". This is a clear appeal to the democratic justification for protecting speech, elevating it above other justifications. While facilitating democracy is without doubt a noble reason for protecting freedom of expression, to prioritise it over other reasons for expression is state centric and ignores the importance of social issues that aren't directly played out in the ballot box. Mr Farrakhan had valid reasons for meeting his supporters in private, and engaging with the international 
head of the movement would be extremely important to them as a disenfranchised minority. The role that expression plays in helping disenfranchised groups understand their place in society is arguably more important than the discussion between those who feel empowered enough to engage with democracy.

Let us turn to the justification used by the Home Secretary. There were many problems with the Secretary's attempt to equate 'community harmony' with a threat to public security. Firstly it did not attempt to address the question of what constitutes a 'fundamental interest', which the Tribunal took a very different view of. The definition given to a threat fundamental interests by the Tribunal, that it must involve a prohibited act' is an aggressive attempt by the Tribunal to protect the freedom of expression of European citizens. Such a definition was available and may have therefore been required by s 3(1) of the Human Rights Act 1998.

One could go further than the Tribunal and suggest that s 21(5) prevents non-criminal prohibited acts, such as breach of the peace, from being considered. The Tribunal cites $R$ (Laporte) v Chief Constable of Gloucestershire ${ }^{94}$ as authority for the proposition that a breach of the peace is a prohibited act. The case concerned anti-war protesters on their way to a protest in a bus who were stopped and turned around (but not arrested) by police. The House of Lords found that police had a reasonable belief that the protesters may have been intending to commit a breach of the peace when they arrived at the protest. That action taken by the police was nonetheless found to be illegitimate because a breach of the peace must be imminent before it can be acted against in this fashion. It is likely the House of

${ }^{94} \mathrm{R}$ (Laporte) v Chief Constable of Gloucestershire [2006] 2 WLR 46 (HL). 
Lords was influenced by Article 10 of the ECHR.$^{95}$ If this same right were to be upheld in an immigration context it would suggest that, since a breach of the peace was in no way imminent upon Wilders arrival at London Heathrow Airport, a belief backed by evidence that Wilders entry to the United Kingdom would lead to a breach of the peace does not justify his exclusion.

Section 21(5)(c) is of particular interest because it appears specifically designed to eliminate the hecklers veto as a justification for exclusion. On the one hand, its presence does suggest that the Tribunal's interpretation of 'fundamental interest' is incorrect. If only the commission of a crime or breach of the peace is sufficient to affect a fundamental interest, then s 21(5)(c) is redundant, since by definition all crimes are based on an individual's conduct (the term being sufficient to cover both an act and omission). ${ }^{96}$ On the other it seems fatal to the link made by the Secretary between the threat Wilders posted to 'community harmony' and public security. Although the Secretary's approach is simply to ask the Tribunal to show deference rather than give specifics about how Wilders visit threatened community harmony, it seems likely the Secretary envisioned a reaction by sections of the Muslim community similar to the 2006 Islamist demonstration outside the Embassy of Denmark in London (where some protesters carried signs reading "Massacre those who insult Islam" and wore mock suicide vests) in response to the Danish Muhammad cartoons. ${ }^{97}$ Any consideration that these types of actions would lead to harm would be a prohibited consideration under s 21(5)(c).

\footnotetext{
${ }^{95}$ At [34].

${ }^{96}$ DJ Baker, G Williams Glanville Williams Textbook of Criminal Law (3rd ed, Sweet and Maxwell, London, 2012)

97 Owen Bowcott "Arrest extremist marchers, police told" (6 February 2006) The Guardian <www.guardian.co.uk>.
} 
Another argument used by the Secretary is that any decision by the government to allow Wilders to enter the United Kingdom would be seen as 'welcoming' him, and thereby implicitly endorsing his views which may promote further community resentment. ${ }^{98}$ The argument is quite rightly dismissed by the Tribunal as troubling. ${ }^{99}$ The fact that this argument was even made seems indicative of the thought process of politically accountable decision makers, who may face a majoritarian backlash simply from the refusal to exercise their powers against people with unpopular views however capricious that exercise of power may be. It shows the need for a hard look approach to review when protecting speech where the power to restrain is so broad.

\footnotetext{
${ }^{98}$ At [32].

99 At [33]
} 


\section{Freedom Of Expression And Freedom Of Movement In Australia: David Irving's Struggle}

\section{A Human Rights Framework In Australia}

Australia essentially has no protection for freedom of expression that is comparable to the New Zealand Bill of Rights Act 1990 or the United Kingdom's Human Rights Act 1998 that exists on a Federal level. Any state level protections would be irrelevant to immigration decisions. When the Australian Constitution was initially debated in the 1890's a proposal to include a Bill of Rights was considered and rejected. ${ }^{100}$

Australia inherited English common law and so many of the equivalent common law protections of human rights nonetheless exists. Furthermore a right to political expression has been read into the Australian Constitution in some High Court cases. ${ }^{101}$

\section{B Background}

David Irving is a British historian who is most prominent for his status as a Holocaust denier. He has written several well publicised books about Nazi Germany and World War Two.

Much of Irving's work is widely discredited. Although Irving has claimed that he is not anti-Semitic and has branded himself as a 'Holocaust revisionist' he has on numerous occasions associated with neo-Nazi groups, expressed anti-Semitic sentiments and denied the existence of any gas chambers at Auschwitz altogether. He has also knowingly used

\footnotetext{
100 "How are Human Rights Protected in Law?" (2006) Australian Human Rights Commission <www.humanrights.gov.au>.

${ }^{101}$ See Lange v Australian Broadcasting Corporation (1997) 189 CLR 520.
} 
fabricated source material to back up his claims. In 1996 Irving sued American author Deborah Lipstadt and her publisher for comments made about him in her book Denying the Holocaust. In a 333 page judgement it was found that all allegations against Irving were substantially true. ${ }^{102}$

Irving has also had multiple serious legal problems associated with his overseas travel and the views he has expressed on the Holocaust. In 1992 Irving was deported from Canada and he has been denied entry to countries including Italy, New Zealand ${ }^{103}$ and Australia. Irving has faced multiple prosecutions for Holocaust denial including facing a 10,000 Deutschmark fine in Germany in 1992. In February 2006 Irving was sentenced to three years in prison in Austria. ${ }^{104}$

In December 1992 Irving lodged an application for a business visitor (short stay) visa to promote sales of his books by way of speaking engagements and media interviews. In February 1993 the Minister of Immigration, Local Government and Ethnic Affairs rejected Mr Irving's application after the Jewish community indicated strong opposition to his visit. He filed for judicial review of that decision. Irving had previously visited Australia in 1986 and 1987 for similar tours without incident.

\section{Decision and Judicial Review}

An applicant is required to meet a number of public interest criteria, defined in regulation 2 in order to receive a business visitor (short stay) visa under the Migration Regulations.

\footnotetext{
102 Irving v Penguin Books Ltd [2000] EWHC QB 115 (UK).

103 "Lawyer bids to get David Irving let in to NZ" (16 September 2004) NZ Herald < www.nzherald.co.nz>. 104 “Holocaust denier Irving is jailed" (20 February 2006) BBC <www.bbc.co.uk>.
} 
After receiving advice, the Minister chose to decline the application because Irving did not meet ground (c) of the public interest criteria. Ground (c) requires that the applicant: ${ }^{105}$

"is not determined by the Minister acting personally to be likely to become involved in activities disruptive to, or violence threatening harm to, the Australian community or a group within the Australian community."

The main guidance on how to interpret this ground comes from the Controversial Visitors Policy drafted by the Department of Immigration, Local Government and Ethnic Affairs. Sections 9.1.1 to 9.1.2 read as follows: ${ }^{106}$

\subsection{1}

"Visitor policy seeks to exclude from Australia person who have planned or participated in, or been active in promoting political motivated violence or criminal violence including particularly acts of terrorism; and/or are likely to propagate or encourage such actions during a visit to Australia. It also seeks to exclude person who may pose some threat or harm to the Australian community."

\subsection{2}

"A proposed visit by a person, the presence of whom in Australia may precipitate the sort of vigorous or controversial debate which may take place in a democratic society, is not sufficient reason to refuse that person a visa"

\footnotetext{
${ }_{105}$ Irving $v$ Minister for Immigration, Local Government and Ethnic Affairs (1993) 44 FCR 540 (WADC), at 546.

${ }^{106}$ Laurence W Maher "Migration Act Visitor Entry Controls and Free Speech: The Case of David Irving" (1994) 16 Sydney Law Review 358 at 367
} 
In a letter to Irving dated March $8^{\text {th }} 1993$ the Minister confirmed the reasons for his decision. The letter states that "the fact that persons may be affronted by your opinions is not relevant. What is of concern is the effect that your presence in Australia will have within the community." The letter went on to specify that "I am satisfied that if I had approved your proposed visit your activities in relation to the promotion of your books would have been disruptive to the Australian community or a group within the Australian community." 107 The initial judicial review, heard by French $\mathrm{J}$ in the Western Australia District Court, was unsuccessful. ${ }^{108}$ The appeal was heard by the Full Court.

The Court was in agreement in quashing the appeal. It found that in order for the Minister to decline the application under (c) he had to be satisfied of two things. Firstly that activities would occur which would be disruptive to the Australian community, and secondly that Irving would be involved in those activities. ${ }^{109}$

Under the first requirement, it was found that vigorous expressions of support for or opposition to the opinions of the authors and minor breaches of the peace would not be sufficient to constitute the type of disruption created by the section. The conduct would have to entail "divisive acts the community would not be expected to tolerate" "threaten the normal cohesiveness of the community" in a harmful way. ${ }^{111}$ It was not required that the division lead to physical violence. The extent to which these events would be expected to be controlled by law enforcement would be an appropriate consideration. ${ }^{112}$

\footnotetext{
${ }^{107}$ At 549 .

${ }^{108}$ Irving v Minister for Immigration, Local Government and Ethnic Affairs (1993) 115 ALR 125 (WADC).

${ }^{109}$ Above at 105, at 551.

${ }^{110}$ At 551.

111 At 544.

${ }^{112}$ At 551 .
} 
Under the second requirement, it was necessary that the visitor would be connected with the occurrence of disruptive events. The connection be more than the mere presence of the visitor in Australia at the time that the activities occurred. ${ }^{113}$ However the applicant need not engage in the activities, it would be sufficient that their presence acted as a focal point for division. ${ }^{114}$

The Court found that the word 'likely' in the section meant that the Minister was required to assess the probability of certain events occurring, and had to show that there was "credible material supporting a conclusion that there was a likelihood". There were two potential divisions that were possible: The first was a potential division between the proponents of free speech and the Jewish community. The second was that the activities engaged in by Irving would disrupt the Jewish community. ${ }^{115}$

The key finding of the Court was that there was not sufficient evidence supporting the conclusion that activities of the type contemplated (book promotion events) would be likely to cause division. There is a statutory grounds for review under the Administrative Decisions (Judicial Review) Act $1977^{116}$ where a decision can be reviewed if "that there was no evidence or other material to justify the making of the decision". The Minister mainly relied upon a somewhat provocative letter sent by the Irving to the editor of the Australian Jewish News concerning his upcoming visit in which he accused the "organised Jewish community" of suppressing public debate through violence, property damage or blackmail in other parts of the world, stating that such tactics "only increase anti-Semitism,

\footnotetext{
113 At 551.

114 At 544.

115 At 544

116 Administrative Decisions (Judicial Review) Act 1977, s 5(1)(h) (Cth)
} 
which I deplore". The Court did not regard this letter as a reasonable basis to conclude that Mr Irving's visit would cause the type of division required by ground (c). The appeal was allowed and the matter was remitted to the Minister for reconsideration.

\section{Analysis}

\section{Level Of 'Involvement'}

The interpretation of the term 'involved' raises a number of significant issues concerning the freedom of expression. While the issue was not decisive, the Court adopted a wide meaning of the term which can be characterised as only slightly more than a 'but for' test for involvement: there must simply be a causal connection between the visit and the disruption. The visitor need not participate in disruption or violence or encourage disruption or violence by their supporters. ${ }^{117}$ The reaction need not be a proportionate, reasonable, justifiable or even logical response to any views expressed by the visitor. This is effectively the enshrinement of the hecklers veto.

The public view of the visitor may not even need to be accurate to create the type of community division that would justify exclusion. Drummond J suggests that inaccurate media narratives may indicate the type of community division that would justify exclusion: ${ }^{118}$

"There may be circumstances in which media comment might be sufficient to justify the Minister in refusing a person entry to Australia...

117 At 551

118 At 567 
The way the media depicts such a person may be a guide, unfair though it will be, if inaccurate, to the reaction by people here to his presence"

The possibility of media driven fear being a direct mechanism to curtail freedom of expression is frightening to those who value human rights. This fear, potentially whipped up by tabloid media and populist fervour is exactly the sort of reaction that should never justify the limitation of freedom of expression. If anything it should justify a right to correct the record and a need for government to encourage participation in the marketplace of ideas.

Drummond $\mathbf{J}$ was also the only judge to explicitly recognise this tension. In his judgement he admits: ${ }^{119}$

"So construing the Regulations and, in particular, criterion (c), has the result that a person can be lawfully excluded from entry to Australia where he has only limited opposition within the Australian community but that opposition is prepared to threaten violence in demonstrating their opposition to him, if he is allowed into the country. This can make freedom of speech a hostage to the willingness of a few already living in Australia to break the law. But I think the Regulations bring the balance down between freedom of speech and the preservation of order and calm within the Australian community in that way"

Although it is argued that the regulations strike a balance, the wide interpretation of 'involved' will never act to protect freedom of expression. The choice of this interpretation can be put down to Australia lacking a genuine human rights framework. Had Australia

119 At 559. 
adopted the equivalent of s 3 of the United Kingdom Human Rights Act 1998 (requiring interpretations of statutes and regulations consistent with Convention rights) the Court may well have adopted a different interpretation. Interpreting involvement as participation in disruptive behaviour is a reading both available to the Court and more consistent with the right to freedom of expression.

Drummond J seeks to justify this wider test for 'involved' by invoking the common law right for a citizen to act against another if they reasonably believe a breach of the peace may occur, and be taken to a magistrate and bound over to ensure that further breaches of the peace do not occur. It is argued that because it is not necessary to show that the speaker will themselves commit a breach of the peace to conduct such an arrest, it would be illogical to impose the same requirement in this regulation. This power has been codified in some jurisdictions. $^{120}$

This seems liked an unfair standard for restricting expression. The right for a citizen to bind over another who they reasonably believe will act in a way which causes a breach of the peace seems archaic in and of itself. It would be unlikely to survive the existence of human rights legislation: authority supporting the ability to bind over someone based on an anticipated breach of the peace by others was overruled in Scotland following the passage of the Human Rights Act $1998 .{ }^{121}$ Nor is this power demonstrably justified in a free and democratic society. Most citizens rely on law enforcement to control violent protests. If there were ever a serious attempt to systematically use this to curtail speech it would likely be very detrimental to freedom of expression.

\footnotetext{
${ }^{120}$ Crimes Act 1961, s 42.

${ }^{121}$ Dyer v Brady (2006) SLT 965 (HCJAC).
} 


\section{Level Of 'Disruption'}

The core reason that the Court overturns the decision is the lack of evidence to suggest that Irving would cause disruption. Firstly it is suggested that the actual evidence that the Minister based his decision on, the letter to the Australian Jewish News, is not capable of leading to the conclusion that Irving would cause disruption. It is noted by the Department of Immigration's Ethnic Affairs Section in their advice to the Minister that Irving's work as a historian does not lend itself to breaching Australian anti-racism laws, and he is unlikely to stir up racial hatred. The advice goes on to suggest that the Controversial Visitors Policy would only be breached by Irving if it could be shown that he would "encourage violent neo-Nazism". ${ }^{122}$ The Minister was advised to seek advice on whether this was possible, but never did so. ${ }^{123}$ This seems to be a fair reading of the policy which shows a genuine concern for freedom of expression.

It is made clear that the hurt feels or 'psychic harm' to the Jewish community would not constitute the required level of disruption at the original hearing, and so this is not considered by the Full Court. The Minister received advice from Mr Parker, the Director of the Entry Policy and Procedures Section of the Ministry to the effect that: ${ }^{124}$

\footnotetext{
"Mr Irving's unconventional views do cause distress among the Jewish community in Australia and thus might be properly considered disruptive to that particular group. It is thus open to you to make a determination that Mr Irving's intended activities in Australia are likely to cause disruption to a group within the Australian community."
}

\footnotetext{
122 At 563 .

${ }^{123}$ At 566.

${ }^{124}$ At 548 .
} 
French J appears to uphold the Minister's decision at the original hearing precisely because the Minister ignores this aspect of the advice on the basis that this was not the stated reason for the decision on the letter dated March $8^{\text {th }}$ sent to Mr Irving. ${ }^{125}$ This creates a disconnect between the law and the political reality for decision makers. Groups like the Jewish community are not likely to resort to violence, but are likely to lobby the Government on decisions where they feel grossly offended by a visitor, rather than for the social benefit of avoiding community division. It is also the offensiveness and unpopularity of Mr Irving's views which make it a politically popular decision to decline his application. Again this shows the importance of a judicial willingness to protect freedom of expression. Judicial deference is likely to see the law subverted for political ends.

Given that hurt feelings was rejected as the type of disruption envisioned by the law, and that Irving is unlikely to spark violent neo-Nazism the Court identifies two potential areas of division: between proponents of free speech and the Jewish community and within the Jewish community. It's hardly credible that serious division will emerge between these first two groups. Despite the turn of phrase, Voltairian 'defend to the death your right to say it' advocates of free speech rarely feel impassioned enough to oppose those who feel offended by certain speech in a confrontation manner. On the second grounds of division it seems far more likely that the Jewish community would be united rather than divided by the presence of Mr Irving.

\section{Implications for administrative law}

125 Above at $\mathrm{n} 108$. 
The regulation which the decision maker must apply here is short and incredibly vague. Key terms in ground (c) could have a wide range of different interpretations and meanings. This created a substantial amount of uncertainty for the Minister, who received a range of different advice about how he could decide the matter. While both the Department of Foreign Affairs and Trade and the Australian Security Intelligence Organization declined to advise against granting the application, and sections within the Department for Immigration, Local Government and Ethnic Affairs did not confirm that Irving breached the Controversial Visitors Policy, the Department of Prime Minister and Cabinet stated that "there would appear to be more than sufficient grounds for refusing a visa if that were the Minister’s inclination."126

Laurence Maher argues that it is important for clarity within immigration law so that it is easily understood. ${ }^{127}$ Statutory and regulatory criteria should be susceptible to proof. Not only would this make the process easier for the applicant and the Minister, it would protect expression as subjective criteria can too easily allow for the quashing of unpopular speech where a deferential approach is taken to review.

In this case the review was enabled by a statutory provision in the Administrative Decisions (Judicial Review) Act 1977 s 5(1)(h). Under this provision decisions can be overturned "where was no evidence or other material to justify the making of the decision". A favourable decision in another review case where a decision was taken under grounds (c) of the regulations was interpreted as authority for the proposition at decisions can be overturned were the evidence was not relevant to or logically probative of the

\footnotetext{
${ }^{126}$ At 562.

${ }^{127}$ Maher "Migration Act Visitor Entry Controls and Free Speech: The Case of David Irving", above at n 106 , at 378.
} 
decision. ${ }^{128129}$ The Court applied this framework without unnecessary deference or conducting a handwringing exercise pondering its own competence relative to that of the Minister. The approach enjoys substantial similarities to that taken in Naik.

The decision revealed a basic failure by the Minister to understand the law he was applying, and an excessive level of deference by the Court at first instance. That level of defence may be attributable to the case occurring in an immigration space, although French $\mathrm{J}$ states no clear reasons for deference and does not appear to regard his own decision as particularly deferential. That Lee $\mathbf{J}$ was also willing to suggest (although not decide) on the grounds that the Ministers decision may have contained a level of manifestly unreasonableness amounting to an error of law is an indictment on the decision. ${ }^{130}$

\section{E Second Decision And Review}

The result of the case was that the decision was remitted back to the Minister for reconsideration. The Minister came to the same result but on different grounds under the public criteria, namely that Irving was not of good character under grounds (a) of the requirements.

Under regulation 4, a person is not of good character if they fall under one of a number of categories: ${ }^{131}$

"(1) For the purposes of these Regulations, a person is to be taken not to be of good character if:

\footnotetext{
${ }^{128}$ Hand v Hell's Angels Motor Cycling Club Inc (1991) 25 ALD 667 (WA).

${ }^{129}$ At 560 .

${ }^{130}$ At 552 .

${ }^{131}$ At 546.
} 
(a) in the case of an applicant for a visa or an entry permit of any class:

(i) the applicant has been assessed by the competent Australian authorities to be a risk, directly or indirectly, to Australian national security; or

(ii) the applicant:

(a) has at any time been convicted of a crime and sentenced to death, to imprisonment for life or to imprisonment for a period of not less than one year or;

(c) has at any time been charged with a crime and either found guilty of having committed the crime while of unsound mind or acquitted on the ground that the crime was committed while the person was of unsound mind; or

(d) has been deported from another country; or

(e) has been excluded from another country in the circumstances prescribed for the purposes of subparagraph 20(1)(d)(vi) of the Act; or

(iii) the applicant has, in the reasonable belief of the Minister, been involved in activities indicating contempt, or disregard, for the law or for human rights;

Under category (d) of regulation 4, Mr Irving is not of good character because of his deportation from Canada. However a finding that the applicant does not meet the good character requirement is not necessarily fatal to an application. Under regulation 143 the Minister can grant the application notwithstanding the failure to satisfy the good character requirement if: ${ }^{132}$

(a) the Minister is satisfied that:

(i) in the case of the circumstance referred to in subparagraph 4(a)(i) (sic) - the circumstance no longer obtains; or

$\overline{132}$ At 556. 
(ii) in the case of conduct referred to in subparagraph 4(a)(ii) (sic) or (iii) (sic) - the applicant has shown by subsequent conduct that he or she is reformed; and

(b) the Minister is satisfied that undue harm would be unlikely to result to the Australian community if the visa or entry permit was granted;

The Minister is given further grounds to reject the application by s $180 \mathrm{~A}$ of the Migration Act: ${ }^{133}$

“(1) The Minister may refuse to grant a visa or an entry permit to a person, or may cancel a valid visa or a valid entry permit that has been granted to a person, if:

(a) subsection (2) applies to the person

(2) This subsection applies to a person if the Minister:

(a) having regard to:

(i) the person's past criminal conduct; or

(ii) the person's general conduct;

is satisfied that the person is not of good character;

Unlike the very specific definition given to 'good character' as a public interest criterion under the regulations, the term good character in the act is not defined.

The Minister adopted a once bitten twice shy attitude to his decision, gathering a robust array of evidence to support his finding that Mr Irving was not of good character. These include his conviction under Holocaust denial laws in Germany and subsequent exclusion from that country, evidence that he lied under oath in proceedings in the United Kingdom,

${ }^{133}$ Migration Act 1958, s 180 (Cth). 
and his deportation from Canada. These were similarly relied upon as evidence that $\mathrm{Mr}$ Irving had not reformed and thus was not entitled to an exemption under regulation 143. Challenges arguing that these were, among other things, irrelevant considerations were unsuccessful.

\section{F Analysis}

It's more difficult to argue that these are not legitimate grounds for adverse findings against Mr Irving. Although the decision has the exact same effect of stopping Mr Irving's book promotion tour, the Minister sought to rely on matters not related to the content of $\mathrm{Mr}$ Irving's views or the reaction to them. The fact that Mr Irving has views which he wishes to express should not excuse his other conduct, which it is legitimate for the state to view suspiciously in an immigration context. The Minister did not seek to rely on the offensive nature of Mr Irving's views as a consideration of his character.

Irving argued that his conviction under German Holocaust denial was an irrelevant consideration because Australia did not have such laws. The Court rejected this argument: ${ }^{134}$

"The conviction in West Germany was not irrelevant and it was not of so little weight that no reasonable decision-maker would give attention to it. Germany, like Australia, is a democratic country and Mr Irving's conduct in that country was an offence against its laws.”

${ }^{134}$ Irving $v$ Minister for Immigration, Local Government and Ethnic Affairs (1995) 59 FCR 423 (WADC) at 432. 
The logic seems to suggest that, provided a country is 'democratic' any offence against its laws will not be deemed an irrelevant consideration because the offence involves expression. That a country is democratic would only be important in certain cases. Clearly one could not argue that a rape conviction in Iran would be an irrelevant consideration because of the authoritarian nature of the regime. Where it may be relevant is with regards to offenses relevant to expression.

There is certainly a strong argument that the conviction was not an irrelevant consideration, because of its similarity to a conviction under hate speech laws and the special reasons that Germany criminalises Holocaust denial, but one the Minister may choose to give weight to. The main issue with this rule is that whether or not a country is 'democratic' is not binary but is a question of degree. Once can imagine cases where the Court may have difficulty if it relied upon such a test. 


\section{$V$ Conclusion}

A variety of frameworks exist to deal with issues regarding the freedom of movement and freedom of expression. Most do not give the full weight to freedom of expression that it deserves, either through allowing a hecklers veto or by accepting dubious grounds for exclusion such as protecting community harmony. These ground would rightly be dismissed in any court if applied to prosecute a citizen for expressing their views. If we value freedom of expression as a tool to improve our society, it is wrong to set double standards for those who can contribute to our discourse but are not citizens.

While the existence of a human rights framework is a useful tool, it does not necessarily lead to a more sound human rights based approach. Courts are always attempting to balance competing considerations, and this means they are not always willing to fulfil their role. As the Farrakhan approach and the approach in the first Irving case demonstrate, sometimes courts show excessive deference in the immigration space. Where the issue purely concerns expression, courts ought to apply a high standard of review to fulfil their role as a protector of human rights. Decision makers often do not apply the law correctly and base their conclusions on weak or irrelevant evidence. Thankfully, more recent case and cases in higher courts tend to demonstrate more of a willingness to do this.

The wider social issues raised by the cases should also not be ignored. While this paper primarily focuses on legal frameworks, it should be observed that all three United Kingdom cases demonstrate a society struggling to deal with the implications of multiculturalism by excluding speakers who claim to represent extreme ends both majority and minority cultures. The decision maker's actions appear to be influenced by a desire to quash potentially inflammatory debate in each case. This is short term thinking, it will never a 
successful strategy to deal with wider issues. Often an outside perspective is necessary to represent unpopular view in a society struggling to deal with that issue. In particular, minorities are in need of strong voices. Social unrest is often an underlying problem that cannot be combatted simply by supressing controversial expression.

Some of the cases dealt with raise issues which plaining are not dealt with in the context of a debate around freedom of expression. This should be no surprise, those with controversial views also lead controversial lives. It was never the case in this paper that those issues should always be discussed within the context of what best promotes freedom of expression, or that freedom of expression will always be the primary issue before decision makers. Two examples of this are the Naik case and the Irving case. In the later the applicant was denied entry on good character ground which were unrelated to his views. It is very reasonable for states to be able to regulate in this way. Past behaviour is a predictor of future behaviour, an applicant with a history of lawlessness or facing deportation from democratic countries could be expected to violate laws in other democratic countries they visit. However where the behaviour being targeted is not illegal behaviour but a view expressed by the visitor, exclusion will rarely be justified. 


\section{Bibliography}

\section{A Legislation}

Bill of Rights Act 1990

Human Rights Act 1998 (UK)

Immigration Act 1971 (UK)

Immigration and Asylum Act 1999 (UK)

Migration Act $1958($ Cth)

\section{B Cases}

A and others $v$ Secretary of State for the Home Department [2005] 2 AC 58 (HL).

$A$ and others $v$ United Kingdom (3455/05), Grand Chamber, ECHR 19 February 2009

Attorney-General for Canada v Cain, Gilhula [1906] A.C. 542 (PC).

Dyer v Brady 2006 SLT 965 (HCJAC).

Farrakhan v Secretary of State for the Home Department [2001] EWHC admin 781 (Ch).

GW (EEA reg: 21: 'fundamental interests') Neatherlands [2009] UKAIT 00050

Irving v Minister for Immigration, Local Government and Ethnic Affairs (1993) 115 ALR 125 (WADC).

Irving v Minister for Immigration, Local Government and Ethnic Affairs (1993) 44 FCR 540 (WADC).

Irving v Minister for Immigration, Local Government and Ethnic Affairs (1995) 59 FCR 423 (WADC).

Irving v Minister for Immigration, Local Government and Ethnic Affairs (1996) 68 FCR 422 (WADC). 
Nishimura Ekiu v U.S. 142 US 651 (1892).

Piermont v France (1995) 20 EHRR 301 (ECHR)

$R$ (Laporte) v Chief Constable of Gloucestershire [2006] 2 WLR 46 (HL).

$R$. (on the application of Farrakhan) v Secretary of State for the Home Department [2002]

3 W.L.R. 481 (CA).

R. (on the application of Naik) v Secretary of State for the Home Department [2010] EWHC $2825(\mathrm{Ch})$

$R$. (on the application of Naik) $v$ Secretary of State for the Home Department [2011] EWCA Civ 1546 (CA)

\section{Treaties}

Agreement between the Governments of the States of the Benelux Economic Union, the Federal Republic of Germany and the French Republic on the gradual abolition of checks at their common borders 30 ILM 68 (signed 14 June 1985).

European Convention on Human Rights ETS 5 (signed 4 November 1950, entered into force 3 September 1953).

D Texts

D Feldman English Public Law (1 ${ }^{\text {st }}$ ed, Oxford University Press, Oxford, 2004)

DJ Baker Glanville Williams Textbook of Criminal Law ( $3^{\text {rd }}$ ed, Sweet and Maxwell, London, 2012).

H Barnett Constitutional and Administrative Law ( $8^{\text {th }}$ ed, Routledge, Oxon, 2011)

J Jowell and D Oliver The Changing Constitution $\left(6^{\text {th }}\right.$ ed, Oxford University Press, Oxford, 2007) 
M Turtle Freedom of Information Manual ( $1^{\text {st }}$ ed, Sweet \& Maxwell Ltd, London, 2005)

P Birkinshaw European Public Law (1 $1^{\text {st }}$ ed, LexisNexis Butterworths Tolley, London, 2003)

R Plender International Migration Law ( $2^{\text {nd }}$ ed, Martinus Nijworth Publishers, Dordrecht, 1988)

\section{E Papers}

Aileen Kavanagh "Defending deference in public law and constitutional theory" (2010) 126 L.Q.R. 222

Laurence W Maher "Migration Act Visitor Entry Controls and Free Speech: The Case of David Irving” (1994) 16 Sydney Law Review 358

Rex T Hadar "The Right to Protection of Religious Feelings" (2008) 11(4) Otago LR. 629.

Steve Foster "The fight against terrorism, detention without trial and human rights" (2009)

14(1) Cov.L.J. 4

F Web

"Ahmadinejad Blasts Israel, Denies Existence of Iranian Gays During Columbia Speech" (24 September 2007) Fox News <www.foxnews.com>.

"Dutch anti-Muslim politician Geert Wilders to screen Fitna film in Washington" (24 February 2009) The Telegraph <www.telegraph.co.uk>.

“Geert Wilders: Man out of Time” (26 January 2009) Assyrian International News Agency <www.aina.org>.

“How are Human Rights Protected in Law?” (2006) Australian Human Rights Commission <www.humanrights.gov.au> 
"Mr Wilders contribution to the parliamentary debate on Islamic activism" (29 September 2007) Geert Wilders Web Blog <www.geertwilders.nl>.

"Violent clashes between Occupy Wall Street protesters and police in New York" (17 November 2011) The Telegraph <www.telegraph.co.uk>.

David Fisher "Glenn Greenwald: New Zealand has spied on friends for US" (17 September 2014) NZ Herald <http://www.nzherald.co.nz/>

Guy Palmer "Poverty Rates amoung Ethnic Groups in Great Britian" (30 April 2007) Joseph Rowntree Foundation <www.jrf.org.uk> .

Haroon Siddique "Dutch politician attempts to defy UK entry ban to show film critical of Qur'an” (12 February 2009) The Guardian <www.theguardian.com>.

Home Office "Report of the Stephen Lawrence Inquiry" (24 February 1999) UK Government <www.gov.uk>.

Neil Reid "Protests Blamed on Bill English" (3 June 2012) Stuff <www.stuff.co.nz>.

Noah Smith “The Dark Side of Globalization: Why Seattle's 1999 Protesters Were Right” (6 January 2014) The Atlantic <www.theatlantic.com>.

Owen Bowcott "Arrest extremist marchers, police told" (6 February 2006) The Guardian <www.guardian.co.uk>.

Rajeev Syal "Parliament failing to represent UKs ethnic diversity" (31 July 2014) The Guardian <www.guardian.co.uk>.

Randeep Ramesh "Black people more likely to be jobless in Britain than US, research reveals" (13 April 2012) The Guardian <www.guardian.co.uk>.

Rosalind English "Farrakhan" One Crown Office Row http://www.1cor.com/1315/?form_1155.replyids=496. 
Vikram Dodd "Racism 'rife in the justice system"” (20 March 2000) The Guardian <www.guardian.co.uk>. 
